\title{
Design of Digital Engineering Practicum Simulator for Vocational High School
}

\author{
Irwan Yusti ${ }^{1}$, Ganefri², Ridwan², Nofriadiman', and Yahfizham ${ }^{3}$ \\ ${ }^{1}$ High School of Industrial Technology (STTIND) Padang, Indonesia \\ ${ }^{2}$ Universitas Negeri Padang, Indonesia \\ ${ }^{3}$ Universitas Islam Negeri (UIN) Medan
}

\section{Abstract}

Secondary School Vocational (SMK) is a school that is expected to produce graduates who have the skills, skills, competence and can compete in the world of industry / business world. This can only be achieved if SMK has sufficient practice equipment. From several studies that have been done about the feasibility of equipment practice in SMK found the fact that most of the SMK does not have sufficient practice equipment. Limited funding and land become the cause of the inability of SMK in providing it. In

Corresponding Author: Irwan Yusti irwan_yusti@yahoo.com

Received: 18 January 2019 Accepted: 24 March 2019 Published: 31 March 2019 Publishing services provided by Knowledge E

(c) Irwan Yusti et al. This article is distributed under the terms of the Creative Commons

Attribution License, which permits unrestricted use and redistribution provided that the original author and source are credited.

Selection and Peer-review unde the responsibility of the ICEST 2018 Conference Committee.

\section{G OPEN ACCESS} order to solve the problem, other practical tools such as software are believed to be able to complement existing practice equipments.

Keywords: SMK, Practice Tools, Software

\section{Introduction}

The Indonesian National Qualification Framework (KKNI) [1] requires graduates of SMK to have competencies that are capable of performing specific tasks as well as having operational knowledge of the basic specific work areas. To achieve the required competence of KKNI, SMK graduate should not only have theoretical ability but also must have the ability in the field of practice. Prosser [2] states "Vocational education will be efficient if the environment in which the student is trained is an environmental replica where he / she will work".

In vocational practice implementation is done in two forms, namely: (1) laboratory in labor and; (2) practice in industrial environment / work world. To implement the practice in schools requires adequate practice equipment, in fact many SMK do not have sufficient practice equipment, this is due to limited funds whereas [2] states that "Vocational education requires a certain fee and if not met then the vocational education should not be forced to operate ". In order for the Vocational School to have sufficient practice 
equipment, it is necessary to develop practical tools at affordable prices and practice can be done anywhere without the need for a special room.

One of the efforts that can be done is to make practice equipment using software in the form of simulation program. The simulation program has been developed by software developers such as Matlab, Proteus and others. Only the software can not follow the steps in the implementation of practicum in school.

The aim of this research is to develop a simulator software that can simulate digital technique material, digital technique material at SMK consists of: (1) digital gate; (2) flipflop; (3) register; (4) encoder-decoder; (5) counter, and equipped with steps of implementation practicum starting from pretest, trial, posttest and making report. With this simulator, SMK with limited equipment practical can have equipment practicum sufficient to increase their graduate competence.

\section{Basic Theory}

Simulations in education have been used more than 30 years ago to adopt the principles of cybernetics that is to analogy human with electromechanical in terms of selfregulating feedback. According to [3] human behavior according to cybernetic psychology, involves clear motion patterns including closed behavior and open behavior. In certain situations, individuals modify their behavior according to the feedback they receive from the environment in other words receiving feedback is a human mechanism for receiving and sending information.

Basically a simulation is an activity or work done in a planned way to present the actual event or work. By simulating the students can improve their understanding of a job, improving understanding can only occur when the

simulation can be used to train students' skills from a simple job to complex work. Training can be given gradually in accordance with the level of ability and understanding of students to the work. In practical learning, simulation using media simulator as learning tool. Simulator is software designed to simulate aactivity practicum, according to [3] "A simulator is a training device that closely represents reality but in which the complexity of events can be controlled". The use of simulators in education has many advantages, among others: (1) enables students to learn according to their ability and speed in understanding the knowledge and information presented; (2) students can control their learning activities, (3) students can determine the learning speed and choose the sequence of activities according to need, (4) can repeat the process to help students who have slow learning speed. [4] 
Outcomes to be achieved in vocational education are competent students, in the field of competency education is a minimum ability qualification of students in terms of knowledge, skills and attitudes, students who have competence will be able to do the tasks assigned to him in accordance with the competence owned. Student competence is assessed from the student's ability to master the cognitive, affective, and psychomotor domains. Cognitive, affective and psychomotor domains are the classification of individual behaviors according to [5], in which learning outcomes are behavioral changes that are divided into three aspects. Cognitive domain is a domain that deals with aspects of intellectual or thinking / reasoning. According to [5],cognitive domains include "(1) knowledge, comprehension, application, analyze, synthesis, and evaluation. Affective domain is the domain associated with emotional aspects such as feelings, interests, attitudes, adherence to the moral and so forth. Affective domain include (1) receiving/attending, responding, valuing, organization, and characterization.Psychomotor domains are domains related to skill aspects involving the function of the nervous system and muscles (neuronmuscular system) and psychic functions. This domain includes (1) readiness (set), imitation, habitual, adaptation, and origination.

\section{Research Methods}

Research method used is research development where the purpose of development research is to produce an effective product that can be used in school, not to test the theory. In this study, researchers used the PLomp development model that describes the R \& D steps in five steps: (1) the initial investigative phase; (2) the design phase; (3) phase of realization / construction; (4) test phase, evaluation and (5) implementation phase. Development steps [6] as shown in 1

In accordance with the use of research model that is $R \& D$ research, this research produces the product in the form of manual practical, worksheet practice of digital engineering and digital simulator practicum which has been validated by experts.

Research data is data that will be used to test the practicality and effectiveness of the product research, data retrieval research done as table 1 


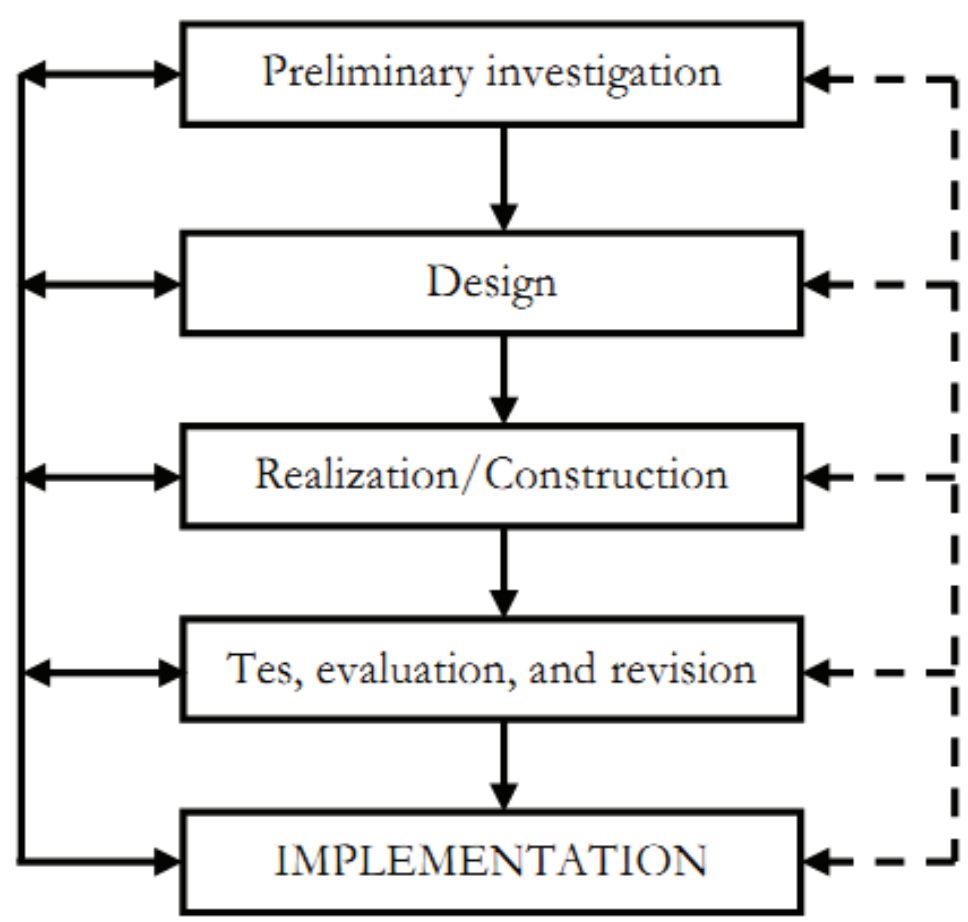

Figure 1: R \& D Plomp Scheme.

TABLE 1: Data Collection Techniques.

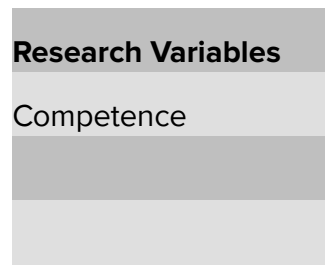

\begin{tabular}{|c|}
\hline Category \\
\hline Affective \\
\hline Cognitive \\
\hline Psychomotor \\
\hline
\end{tabular}

Techniques Taken

Questionnaire

Testing

Performance

\section{Design}

Simulator to be made in this study is simulator that can simulate all the material of digital technique, therefore simulator is divided into several modules where each module can simulate one material of digital technique. The module modules are:

\subsection{Basic gate module}

The basic gate module is a module that can simulate the characteristics of the basic gates and combined gates. The design of the module as shown in 2 


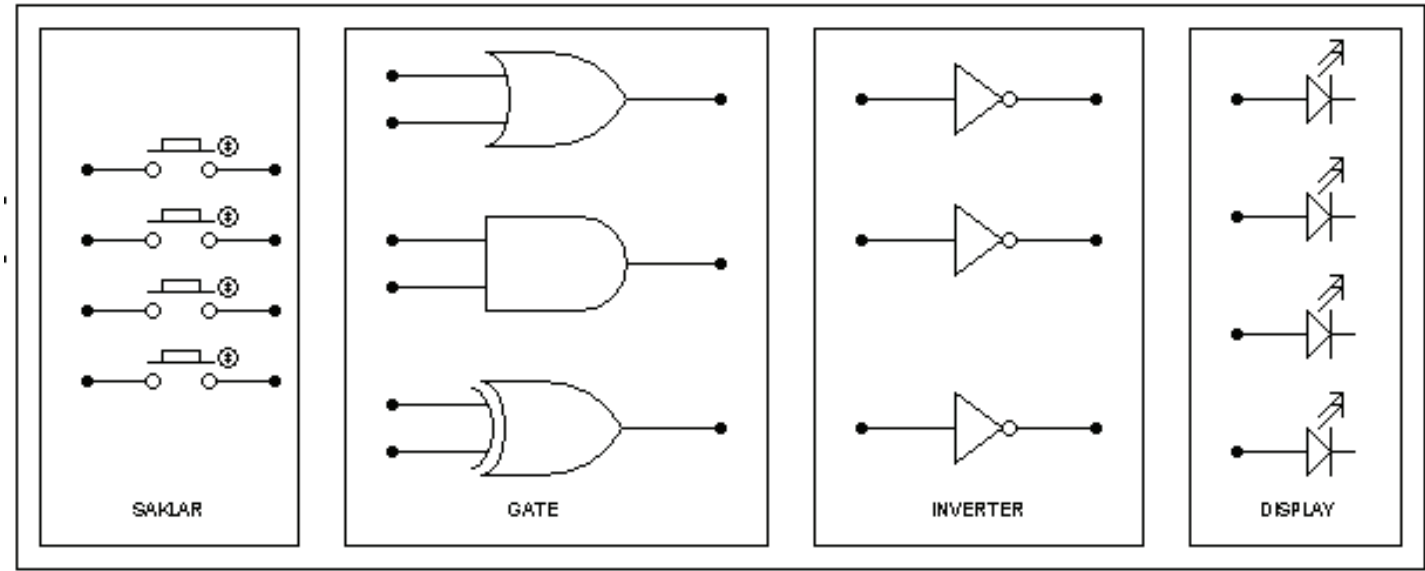

Figure 2: Design of the Basic Gate.

\subsection{Module flip-flop}

Module The flip-flop module is a module that can simulate the characteristics of the flip-flop. Flip-flop module design as shown in Figure 3

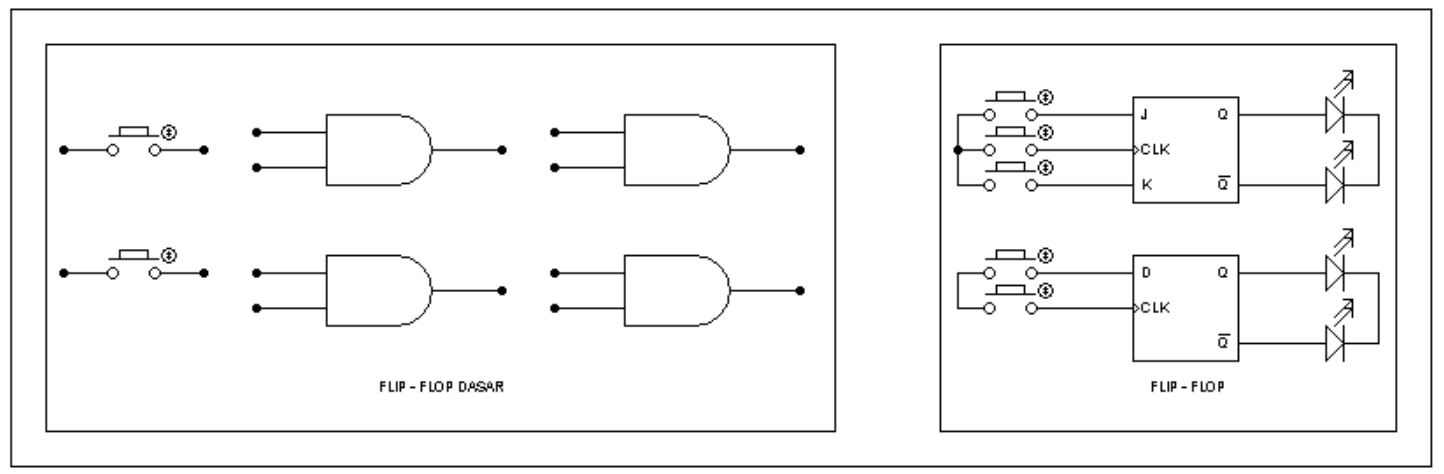

Figure 3: Module Design Flip-Flop.

\subsection{Register module}

In the register module, students can view and test the characteristics of the register. The design of the register module as shown in 4

\subsection{Module decoder}

The decoder module is used to study the decoder characteristics and test the decoder circuit. The design of the decoder module as shown in 5 


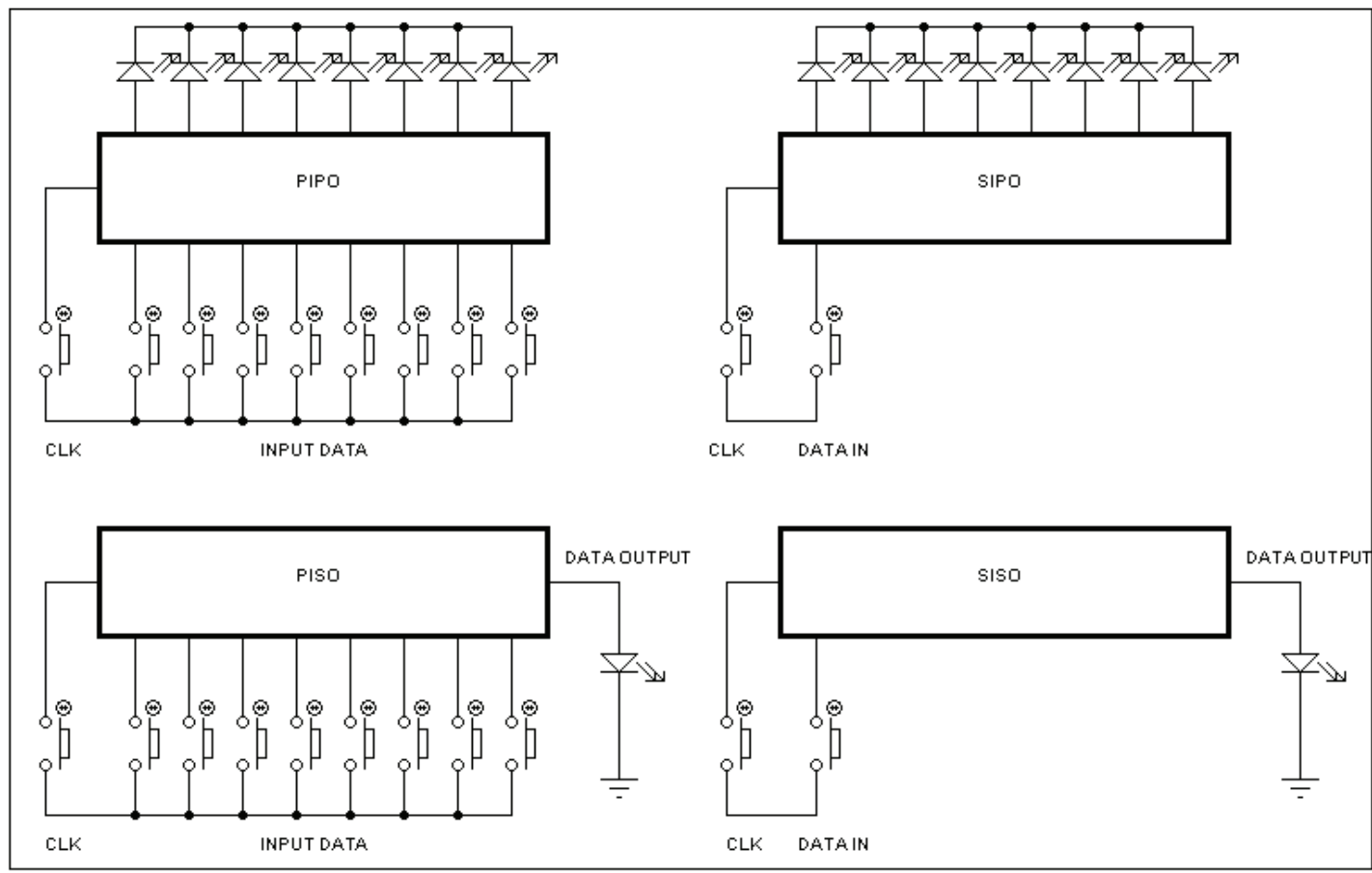

Figure 4: Module Design Register,

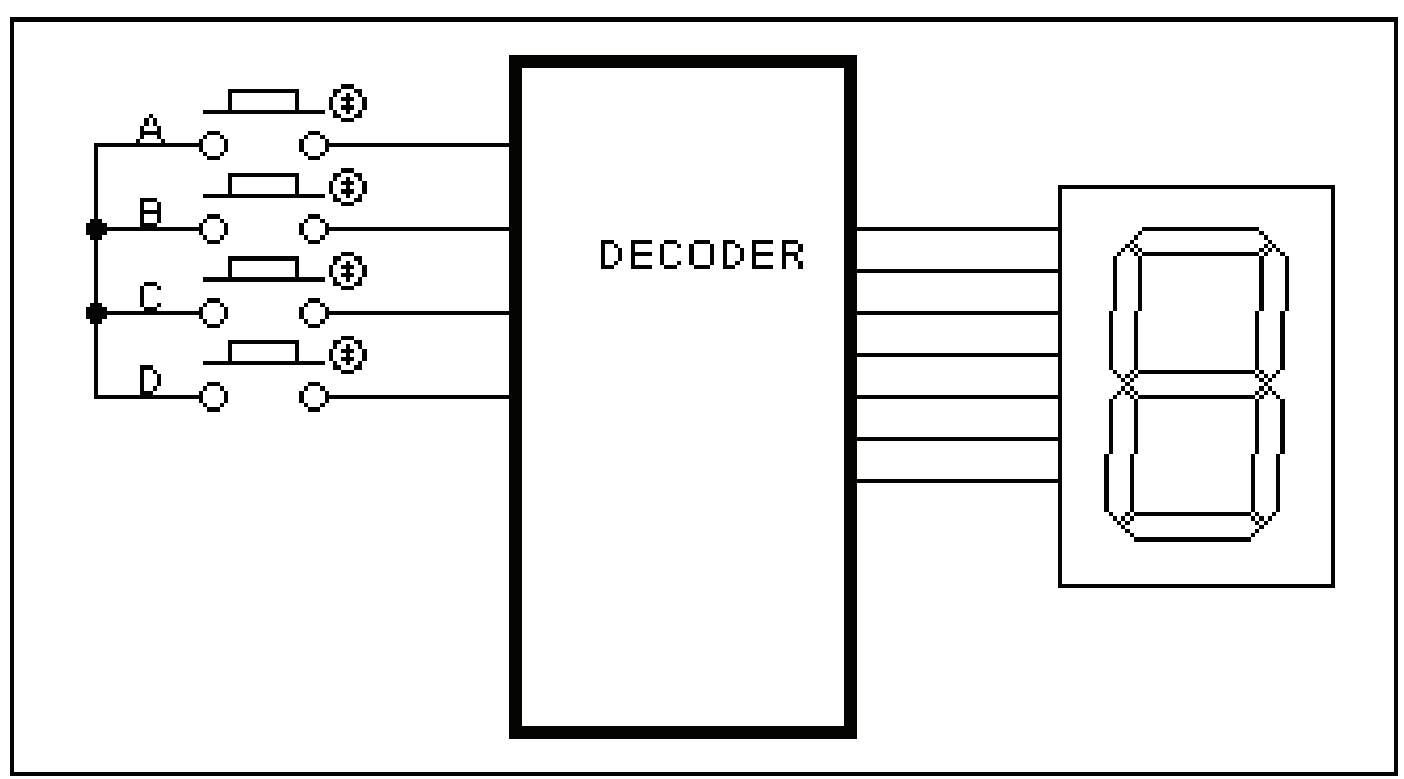

Figure 5: The Module Decoder.

\subsection{Form pretest}

form is used to test the students' initial ability before doing the practicum, the student must answer at least 3 questions from the five questions presented, if the student can not answer 3 questions then the students are required to follow the remedial provided by 
the simulator, after which the student must re-follow the process from the beginning.form design such as Figure 6

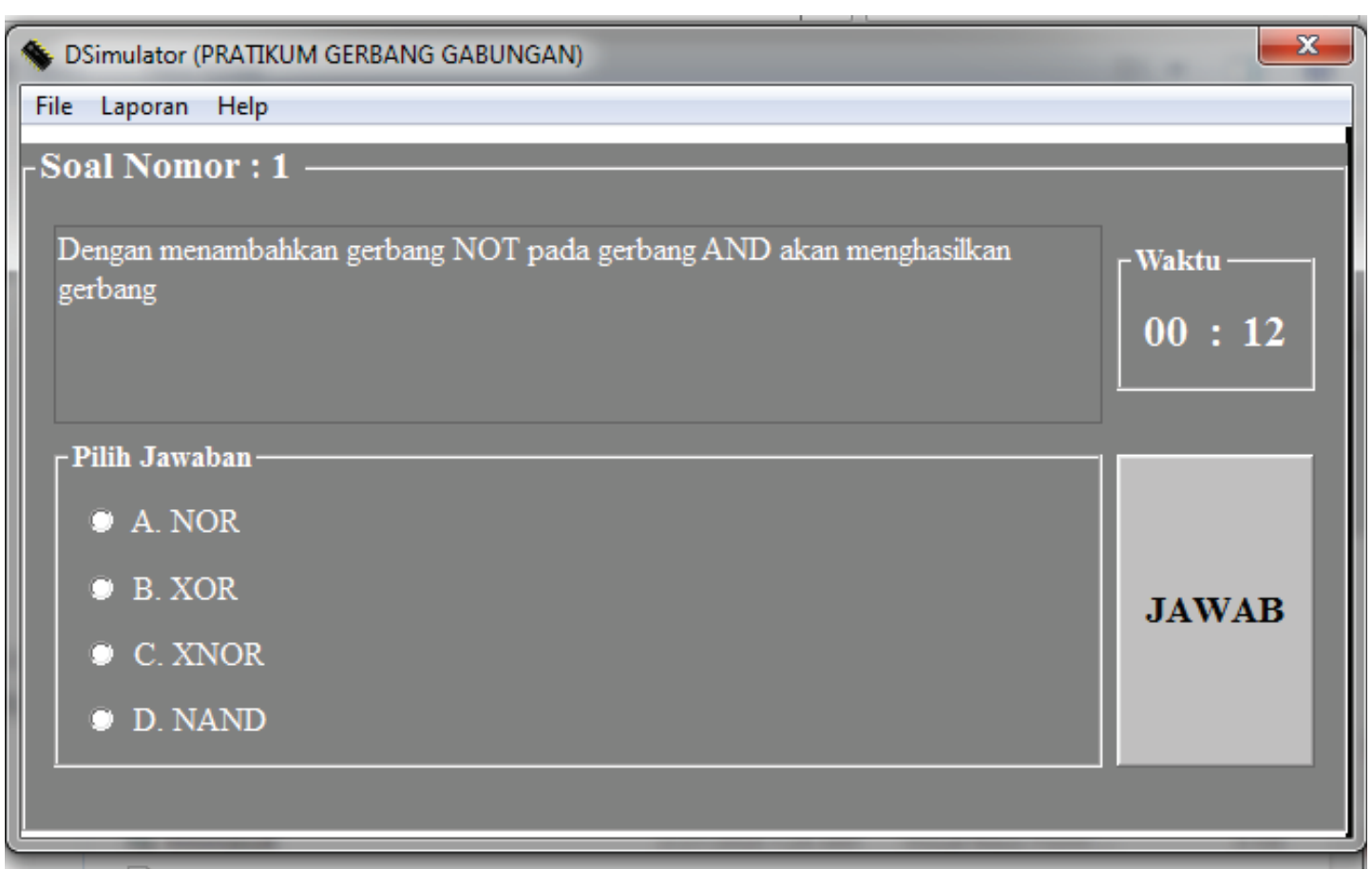

Figure 6: Pretest Form Design.

\section{Results}

Result of this research is a simulator software that can be used for practicum basics of digital technique, manual practical and worksheet practice of digital engineering. Procedures for the use simulators practicator of digital engineering such as Figure 7

Figure 7 can be explained as follows:

1. Before students do practicum, students must fill in an identity consisting of name, NIS, class, school name. This identity will be used as student identity in the report practice

2. Furthermore students must follow the pretest provided by the system. The system will display 5 questions randomly from the number of questions available in the database of questions and the student must be able to correctly answer at least 3 questions. If students can not answer correctly 3 questions then students are required to follow remedial program provided by the system.

3. Implementation of the practicum is done in accordance with the worksheet that has been provided 


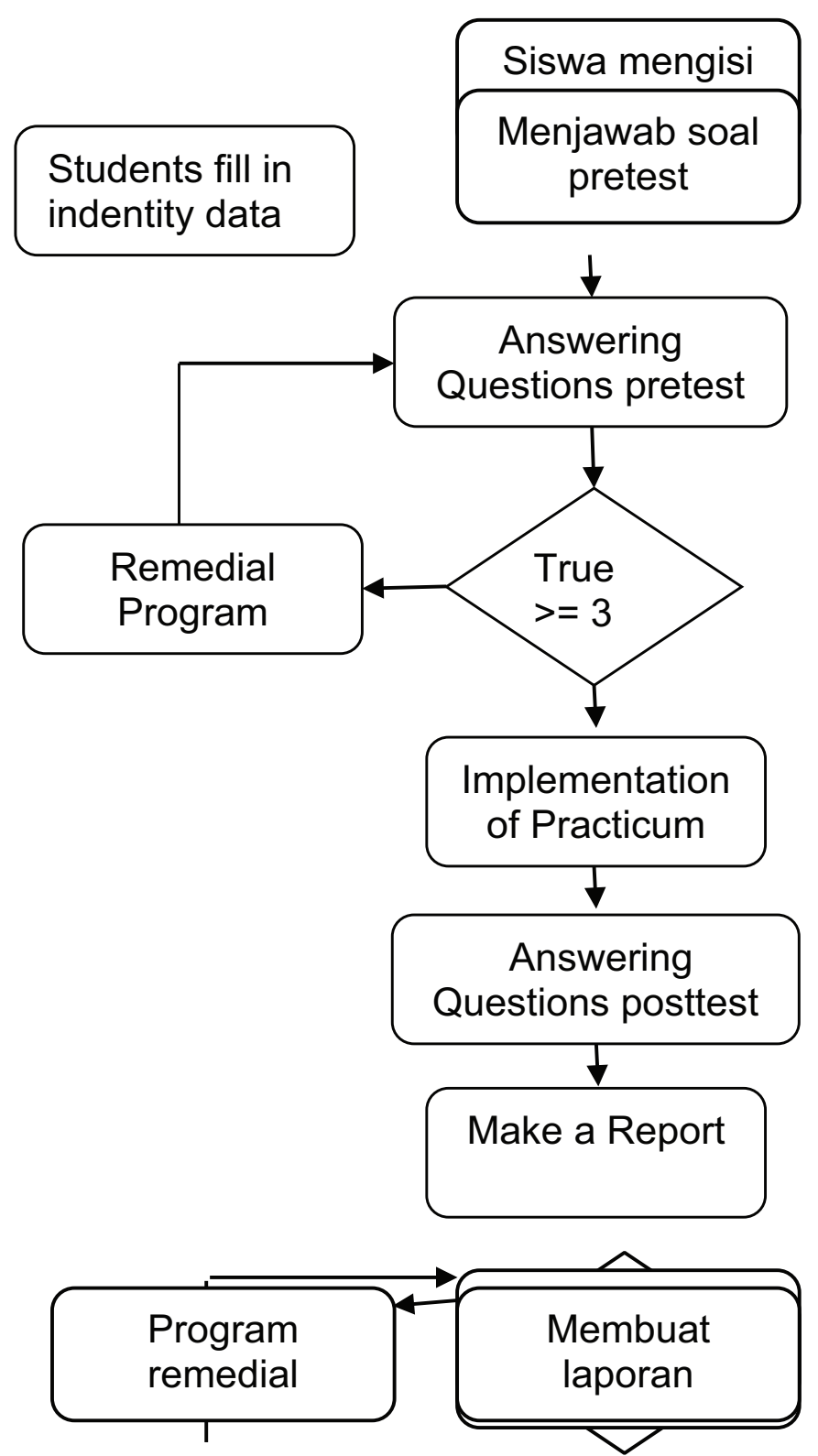

Figure 7: Procedures for the implementation of a practicum with a simulator.

4. After the practicum is implemented, the student must follow the posttest provided by the system, posttest consists of 5 questions randomly displayed from the number of questions available in the database about

5. System will display the report format that must be completed by the students, the pretest and posttest values obtained by the students are available on the report format. 


\section{SMK Semen Padang}

JL, Komp, Sosial PT. Semen Padang

Telp: (0751)

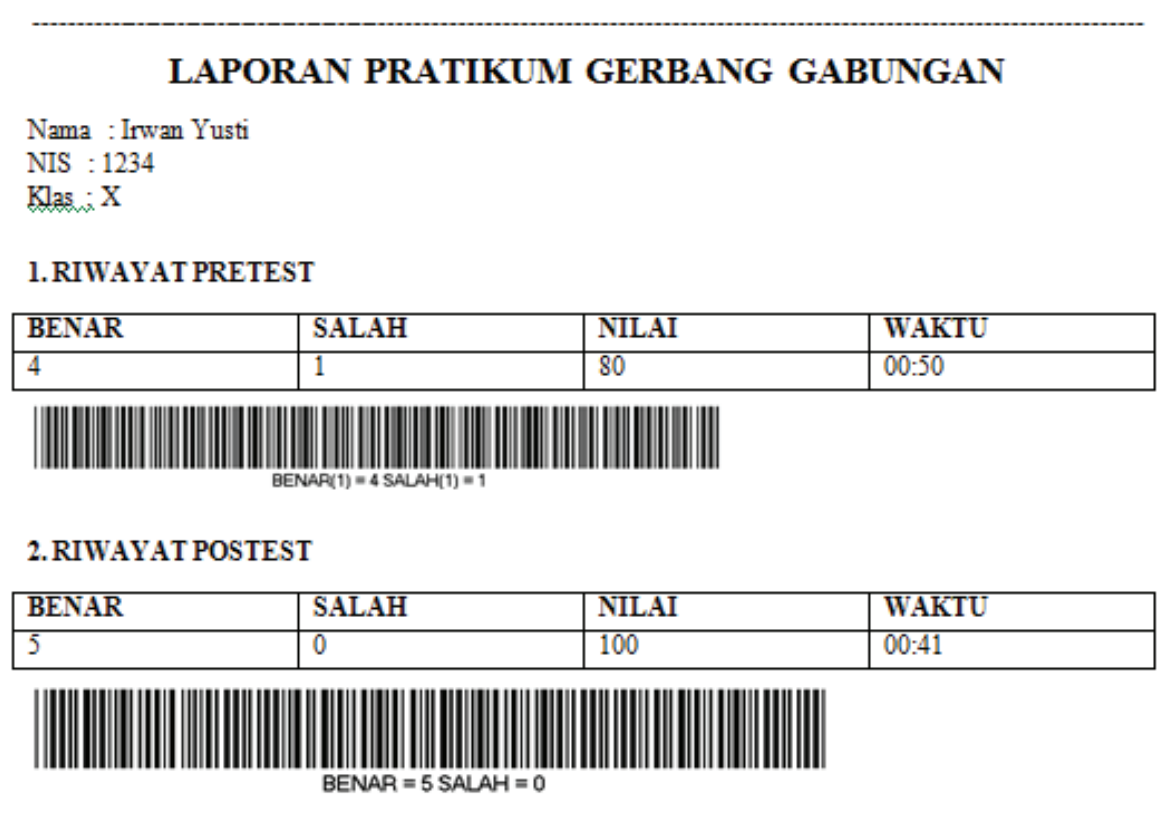

3. ALAT DAN BAHAN

Figure 8: Example of the report format.

\section{Conclusion}

The simulator practicum digital engineering that the researcher develops is still in the form of the design, although this application has been tested in a group of vocational high school students. The aim of the experiment is to see students' responses to simulators practicum the digital engineering that the researcher develops. From the results of the test can be seen that the students give a good response to the results of this study and some advice given by teachers to repair

\section{Acknowledgement}

Thanks researchers to the Prof Ganefri and DR Ridwan who have provided insert and suggestions on this research so that research can be completed. Thank you also to Mr. Nofriadiman and Mr. Yahfizham who have been helpful in this research 


\section{References}

[1] Perpres nomor 8 tahun tentang Kerangka Kualifikasi Nasional Indonesi. Jakarta, 2012

[2] Prosser, CA \& Quigley, TH "Vocational Education in a Democracy" American Technical Society, Chicago, Illinois, 1949.

[3] Joyce, Bruce. Marsha Weil. "Models of Teaching, 5th ed." Prentice Hall, Inc., USA, 2003

[4] Computer Based Learning Simulation Methods_wendaally.html (accessed July 10, 2018)

[5] Anderson. Lorin. W, et.al "A Taxonomy for Learning Teaching and Assessing" Addison Wesley Longman. Inc. 2001

[6] Plomp, Tj. "Educational Design: Introduction. From Tjeerd Plomp (eds). Educational \& Training System Design: Introduction. Design of Education and Training (in Dutch).Utrecht (the Netherlands) "Lemma. Netherland. Faculty of Educational Science and Technology, University of Twente, 1994

[7] Malvino. Albert Paul, Donald. P. Leach, Goutam Saha "Digital Principles and Aplications, 7th ed" Tata McGraw Hill. 2011

[8] Direktorat Pembinaan SMK tentang Pedoman Penilaian Pencapaian Kompetensi Peserta Didik SMK, Jakarta 2013

[9] Yusti, Irwan, Yahfizham, M. Ihsan "Model Development of Learning Digital Techniques Practicum in Vocational High Schoo, Using Simulation Program" Proceeding Aptekindo 8th, Medan. 2016

[10] Yusti. Irwan “ Pengembangan Model Pembelajaran Praktikum Menggunakan Program Simulasi”. Proceeding TVET $3^{\text {rd }}$, Bukittinggi.2015

[11] Yusti. Irwan, Ganefri, Ridwan “Design Of Simulator For Replacement Of Tools Practice Digital Engineering In The Vocational School” Proceeding TVET $4^{\text {th }}$. Padang.2017 